17. Hirschfield J S and Kern, F. Jr.: Protein starvation and the small intestinc III. Incorporation of orally and intraperitoneally administered 1 -ledecine 4.5-3 I into intestinal mucosal protein of protein-deprived rats. I. (lin. Invest. 48: 1224 (1969)

18. Hindmarsh, J. T.. Kilhy, D.. Ross, B.. and Wiseman. (; .: Further studies on intestinal active transport during semistarvation. J. Physiol. (1 ond.), I88. $207(1967)$.

19. Kershaw, T. (;. Neame, K. 1).. and Wiseman. (;.: The effect of semistarvaltion on athorption by the ralt small intestine in vitro and in vivo. J. Physiol. (I.ond.). 1.52: $182(1960)$.

20. Lis, M. T., (rampton, R. F., and Matthews, 1). M.: Rates of aborotion of the dipeptide and the equivalent free amino acid in various mammalian species. Biochim. Biophys. Actit. 23.3: 453 (1971).

21. Loh, K.-R. Shrader, R. F... and Zeman, F. J.: Fitfect of maternal protein deprivation on neonatal intestinal absorption. J. Nutr.. I0I: 1661 (1971)

22. Mahhoob. S. and Zeman. F. J.: Dipeptidases in the intestine of the prenatally protein-deprived rat. Nutr. Rep. Intern.. 14: 42.3 (1976)

23. Matthews, D. M.: Absorption of peptides hy mammalian intestine. In: Peptide Transport in Protein Nutrition. D. M. Matthews and J. W. Paync: (North Holland Publishing ( 11. Amsterdam, 1975).

24. Matthews, D M Craft, I. I Cieddes, D. M. Wise I. J. and Hyde, (C. IV Ahsorption of glycine and glycine peptides from the small intestine of the rat. Clin. Sci.. $35:+15(196 x)$

25. Neale, R. J., and Wiseman. G.: The use of detary-restricted rat intestine for active transport studies 1 Physiol (Lond. 205: 159)(1969)

26. Neame. K. D., and Wiseman. (3.: The effect of diet on intestinal active transport. J. Physiol. (l.ond.), 146: 10P (1959)

27. Newey, H., and Smyth. D. H.: The intestinal absorption of some dipeptides J. Physiol. (L.ond.). 145: 48 (1959).

28. Noall M. W Riges, T R.. Walker L M and Christensen, H. N. Endocrine control of amino acid transfer: Distribution of an unmetabolizable amino acid. Science, 126: 1002 (1957).

29. Schedl, H. P.. Miller, D. I... Wilson, H. D.. and Flores, P.: a-Aminoisobu tyric acid transport and tisste concentration at various sites. Amer. J Physiol., 2/6: 1131 (1969)

30. Shrader. R. E.. Ferlatte, M. I.. and Zeman, F. J.: Farly postnatal develop ment of the intestine in progeny of protein-deprived rats. Biol. Neonate 31 $181(1977)$.

31. Shrader. R. E... and Zeman. F. J.: I:ffect of maternal protein deprivation on morphological and enzymatic development of neonatal rat tissue. J. Nutr.. 49: 401 (1969)

32. Smyth. D. H.: Methods of studying intestinal ahoortpion. Biomembrances. 4A: $241(1974)$

33. Wapnir, $\mathrm{R}, \mathrm{A}$, and $\mathrm{l}$ if shitz, $\mathrm{F}$ : Absorption of amino acids in malnourished rats. J. Nutr., 104: 843 (1974)

34. Wiscman. (3.: Ahorption of protein digestion products. Biomembranes ta: $36.3(1474)$

35. Younoszati, M. K.. and Ranshaw. J.: (Bastrointestinal growth in the fetus and suckling rat pups: Effects of maternal dietary protein. J. Nutr., /10.3: 4.54 (197.3)

36. Zeman, F. J., and Fratzke, M. L..: l.ipid athorption in the young of proteindeficient rats. I.ipids, 11: $652(1976)$

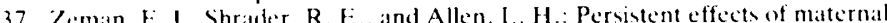
protein deficiency in postnatal rats. Nutr. Rep. Intern.. 7: 421 (197.3)

38. Zeman. F. J.. and Widdowson. $:$. M.: l.ipid absorption in newhorn young of guineat pigs fed a protein-deficient diet during gestation. Biol. Neonate, 24 . $34+(1974)$

39. Salt content of diet (grams per $\mathrm{kg}$ ) wats $\left(\mathrm{aC}()_{3}, 18.0 ; \mathrm{K}_{2} \mathrm{HPO}\right)_{4}, 19.5 ;(\mathrm{aHPO})$ 3.6: $\mathrm{Nil}\left(1,10.08\right.$ : $\mathrm{FSO}\left(0_{4} \cdot 71 \mathrm{H}_{2}(), 1.5: \mathrm{MgS}()_{4} \cdot 7 \mathrm{H}_{2}(), 7.5 ; \mathrm{KI}, 0.015\right.$; $\mathrm{ZnC}\left(\mathrm{O}_{3}, 0.04 \mathrm{C}:(\mathrm{USO})_{4} \cdot 5 \mathrm{H}_{2} \mathrm{O}, 0.018\right.$; and $\mathrm{MnSO}_{4} \cdot \mathrm{H}_{2} \mathrm{O}, 0.1 .38$

40. Calculated on a per day basis, each pregnant animal received: (in milligrams) choline chloride 200 . inositol, 10.0 ; ascorbic acid, 2.0; calcium pantothenate. 1.0; (in micrograms) $p$-aminohenzoic acid. 2000.0 ; pyridoxine. 600.0 ; nicotinic acid, 600.0 ; thiamin, 600.0 ; menadione. 500.0 ; riboflavin. 200.0 ; folic acid. 12.0) biotin. 5.0) vitamin $B_{12}$, ().6; (in international units) retiny pilmitate 300; cholecalciferol, 30.0); and D) - $k$-tocopheryl acetate, 2.2

41. We wish to express our appreciation to Merck and ('). Rathuay. N.J.. for supplying ascorbic acid, (at pantothenate, thiamin-flCl. riboflavin, pyridoxine and vitamin $B_{1,2}$, and Hoffmann-IaRoche. Inc.. Nutley. N. J. for vitamins $A, D$. and 1 .

42. This investigation was supported in part hy Public Health Service (irant 110-(0646.5 from the National Institute of Child Health and Human Development.

43. Requests for reprints should be addressed to: F. J. 7eman. Ph. D.. Department of Nutrition. University of ( aliforniat, Davis, (alif. 956/6 (USA).

44. Received for publication ()etoher 13.1976

45. Accepted for publication February 15,1977

\title{
Human Tracheobronchial Secretions: Development of Mucous Glycoprotein and Lysozyme-secreting Systems
}

\author{
THOMAS F. BOAT (22) JEROMF I. KLEINERMAN, AVROY A. FANAROFF, AND ROBERT ('. STERN

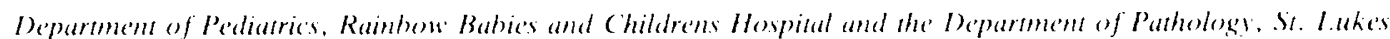 \\ Hospital, Case Western Reserve University, School of Medicine. Cleveldend. Ohio, USA
}

\section{Summary}

Baseline rates for secretion of mucous glycoprotein were simiIar $(680-830 \mu \mathrm{g} / \mathrm{g}$ tissue $/ 24 \mathrm{hr})$ for cultured tracheal epithelium from newborns of 26-32 weeks' gestation, full term newborns, and older children. Addition of methacholine to culture medium augmented secretory rates of glycoprotein from all tissue sources 3-5-fold. The overall composition of secreted mucous glycoproteins changed little with increasing age. A trend toward less sulfation and toward increased sialic acid and fucose content was noted in secreted glycoproteins from explants of older subjects.
Histochemical observations of stored glycoprotein in tracheal tissue, which was subsequently used for organ culture experiments, confirmed that a modest, but consistent sulfate to sialic acid shift occurs during early life. In contrast, baseline secretory rates for lysozyme from tracheal epithelium of preterm infants were one-half as large as rates from epithelium of full term babies and were refractory to cholinergic stimulation. Stimulation of lysozyme secretion by a cholinergic agonist was achieved in all cases by 40 weeks gestation. We conclude that basal glycoprotein secretion and the mechanism for glycoprotein response to cholinergic stimulation have developed by the earliest 
age of viability, but that basal lysozyme secretion is deficient and is unresponsive to cholinergic stimulation in tracheal tissue from preterm newborns.

\section{Speculation}

The lungs of preterm infants may be more susceptible to bacterial invasion than lungs of full term infants and older children as a result of deficient lysozyme secretion by tracheobronchial epithelium.

Development of the human tracheohronchial secretory system begins late in the first trimester of gestation (7). Cilandular mucus-secreting cells appear between 14 and 17 wecks (6) but serous cells are not found in glands until late in gestation (7). Mucus-secreting (goblet) cells of the surface epithelium also appear during the second trimester (6).

According to Lamb and Reid (9). secretory material stored in gland cells of newborn infants and fetuses stains uniformly for sulfate but not at all for sialic acids, in contrast to glands of older children and adults which contain cells with staining reactions for both sulfated and sialylated glycoproteins. Little is known about the actual secretory activity of this tissue. Both lysozyme and mucous glycoproteins are synthesized and released by cultured tracheobronchial epithelium of preterm and term newborn infants (5). The composition of tracheobronchial secretions at various stages of development has not been delineated. We have employed organ culture. chemical, and histochemical techniques to determine the lysozyme and mucous glycoprotein content of tracheal secretions and the response of these secretory compernents to cholinergic stimulation (3) from the earliest age of viability through childhood.

\section{MATERIAIS AND METHODS}

Tracheal explants were obtained from preterm infants (19) with birth weights of $500-1100 \mathrm{~g}$ and estimated gestational ages of 26-32 wecks. These infants had succumbed to pulmomary immaturity between 1 and 6 days of life. All full term infants weighed more than $2500 \mathrm{~g}$ and had dicd within the first month of life of nonpulmonary diseases. (Older children also died of nonpulmonary causes. None of the subjects had breathed more than 70 " oxygen for more than $36 \mathrm{hr}$

Tracheas were removed within 2 hr of death. Newhorn tracheas were cut into $2-4-\mathrm{mm}^{2}$ pieces and cultured as full thickness explants. The submucosa-mucosa layers of tracheas from older children were microdissected from the underlying cartilate and serosa to improve oxygenation and nutrient diffusion to gland cells during organ culture. These layers were also cultured as 2$4-\mathrm{mm}^{2}$ explants. Tissue weights were obtained by weighing culture dishes before and after addition of explants.

Explants were cultured in sufficient log (Fagles base)medium to provide a level even with but not covering the surface of explants as previously described (5). (ientamicin (100) $\mu \mathrm{g} / \mathrm{ml})$ and amphotericin $(10 \mu \mathrm{g} / \mathrm{ml})$ were added to all culture media. In some experiments $6 \times 10^{6} \mathrm{dpm} / \mathrm{ml} \mathrm{N} \mathrm{Na}_{2}^{35} \mathrm{~S}()_{4}$ and $1 \times$ $10^{6} \mathrm{dpm} / \mathrm{ml}$ 6-D-| ${ }^{3} \mathrm{H} \mid \mathrm{glucosamine}$ were also added to the culture medium. Explants were cultured in a $40 \pm 1 \%$ oxygen. $5 \%$ ( water-saturated environment. Medium was removed and replaced every $24 \mathrm{hr}$ for studies of haseline secretory rates.

Experiments testing the response to methacholine stimulation utilized an initial 2()-hr baseline culture period $\left(P_{1}\right)$ and a second 4-hr culture period $\left(P_{2}\right)$ during which $30 \mu \mathrm{g} / \mathrm{ml}$ of methacheline hydrochloride (Sigma) was added to Petri dishes (3). Datal for these experiments are reported as $P_{2} / P_{1}$ ratios of the rate at which nondialyzable material was discharged into the medium. Use of the ratio controls for variability in the secretory capacity of different sets of explants (3).

Harvested media were analyzed for lysozyme by the method of Osserman (14), dialyzed exhaustively against distilled water.

subjected to methanolysis, and analyzed further for fucose, galactose, total hexosamine, and sialic acid content by gas liquid chromatography of the trimethylsilyl sugar derivatives (4). Nondialyzable " $\mathrm{H}$ and ${ }^{35} \mathrm{SO}_{4}$ were assayed by double isotope methods (4). Previous studies had shown that $80 \%$ or more of these two radioactive precursors incorporated into macromolecules by tracheal explants are, in fact, incorporated into mucous glycoproteins (5). Mucous glycoprotein was determined chemically by calculating the sum of its five sugars in dialyzed medium and multiplying this sum by 1.25 (1) to atdjust for the $20 \%$ peptide content of human tracheobronchial mucous glycoproteins (2).

Two or three segments of each trachea. taken at different levels. were placed in neutral buffered formalin and processed for histologic and histochemical studies. Stains routinely employed included alcian blue $(A B)$ at $\mathrm{pH} 1.0$ or 2.5 followed by periodic acid-Schiff (PAS) (12). AB ( $\mathrm{pH} 2.5)$-acid fuchsin (AF) (16), and high iron diamine (HID)- $A B(\mathrm{pH} 2.5)$. The $A B(\mathrm{pH}$ 2.5)-PAS staining sequence was performed both before and after overnight treatment with $1: 4$ diluted Vibrio choleras sialidase as described hy Lamb and Reid (8). Control sections were incubated with buffer alone and compared with sialidase-treated sections for all observations. $\mathrm{AB}(\mathrm{pH} 2.5)$ stains all acidic substances (sulfate and sialic acid) blue whereas at $\mathrm{pH} 1.0$, only sulfated materials are stained blue. The AB-AF staining sequence stains sulfated materials purple and materials containing only carboxyl (sialic) acidic groups blue. HID-AB stains sulfated substances brown-black whereas sialic acid-containing substances are stained blue.

The percentage of total mucous gland cells yielding a characteristic color reaction was estimated by two observers (JK, TB) by directly counting each cell type in all gland acini appearing in multiple sections of tracheal explants. The estimates, performed independently on two occasions. Were reproducible. The small amounts of tracheal tissue which could be alloted from newhorn tracheals for histochemical, rather than culture, stadies precluded precise quantitation of cells giving a particular staining reatetion. Perentage data were grouped into quartiles between 0 and 100 to emphasize that the numbers are carcfully determined estimates.

\section{RFSUITS}

Baseline rates for secretion of mucous glycoprotein and lysezyme by tracheal explants during the first $72 \mathrm{hr}$ of culture are recorded in Table 1 . Mucous glycoprotein was discharged into the culture medium at approximately the same rate by tracheal explants from preterm infants. term infants, and older children. On the other hand, baseline rates for lysozyme secretion by explants of term newhorns were double that of explants from preterm infants. and were even greater in explants from older children.

Explants from six preterm infants responded to methacholine stimulation by discharging mucous glycoprotein at a rate which Was 3-5 times greater than the rate under nonstimulated culture conditions (Fig. la). However. the rate of secretion of lysozyme did not change with addition of methacholine to culture medium bathing preterm explants. Explants from term newborms discharged both lysozyme and mucous glycoprotein in response to methacholine at a rate significantly faster than the baseline rate

Table 1. Bascline secretory rates for cultured tracheal epithelium

$$
\text { Ratc, } \mu \mathrm{g} / \mathrm{g} \text { tissuc } / 2+\mathrm{hr} \pm \mathrm{SEM}
$$

Tracthea source

Premature newhorns

Term newhorms

('hildren (2-8 years)

$$
\text { No. of }
$$$$
\text { tratcheas }
$$$$
8
$$

5
Mucous glycoprotein

$$
8.30 \pm 226
$$

$81 \pm 12$ (f) 0.02$)$

$164+29$

$24+ \pm \times 1$
$746 \pm 214$ $680 \pm 120$ 
(Fig. 1b). The increase in rate of mucous glycoprotein secretion was comparable with that of tracheal explants from preterm infants.

The chemical properties of mucous glycoproteins discharged into culture medium by explants from premature newborns. term newhorns, and older children were compared with respect to ${ }^{35} \mathrm{SO}_{4} /{ }^{3} \mathrm{H}$, sialic acid/galactose, and fucose/galactose ratios (Table 2). Incorporation of "H glucosamine into mucous glyeoprotein as well ats galactose and hexosamine content of mucous glycoproteins discharged in vitro did not change appreciably as a function of the gestational or postnatal age of the tissue donor. Therefore, differences of ratios noted in these studies reflect changes in the ${ }^{35} \mathrm{SO}_{4}$, sialic acid, or fucose content. Although mean ${ }^{35} \mathrm{SO}_{4} /{ }^{3} \mathrm{H}$ rattios decreased from 0.32 in glycoproteins from preterm explants to 0.23 in glycoproteins from explants of older children. these differences did not achieve statistical significance. Similarly, the apparent small increase of sialic acid/galac-
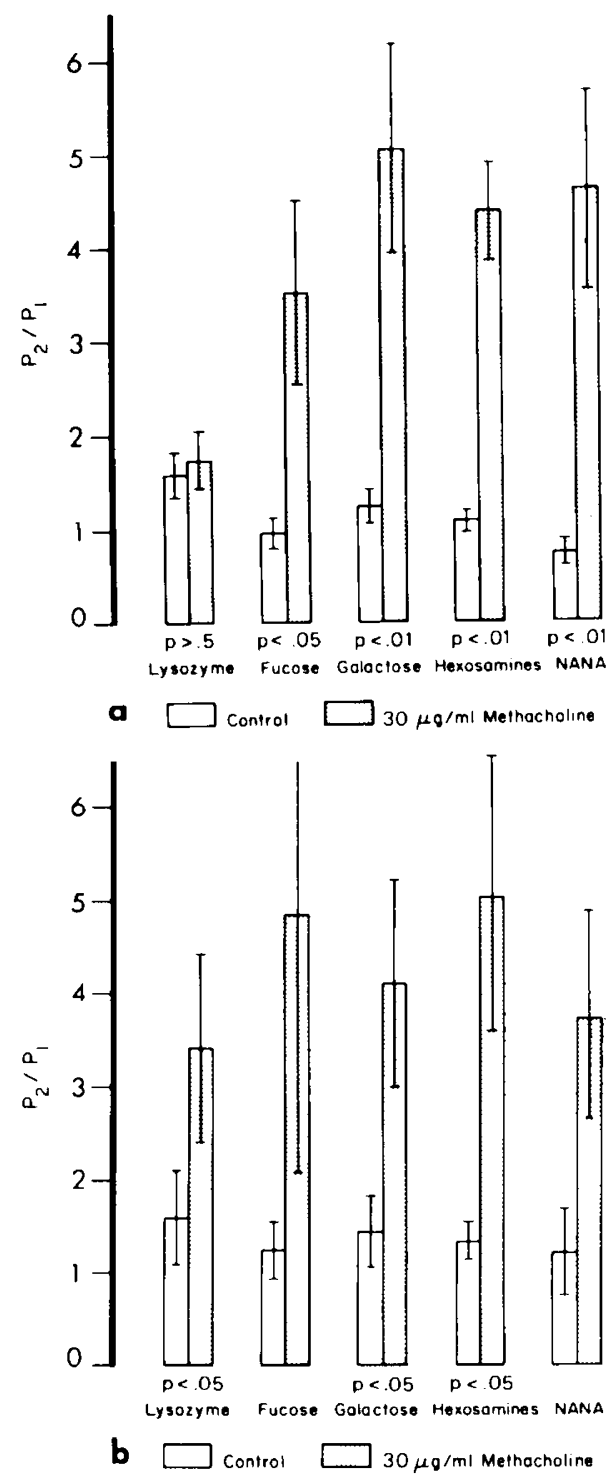

Fig. 1. Methacholine stimulation of secretion by tracheal explants from six preterm newborn infants $(a)$ and four term newborns $(b)$. $\mathrm{P}_{2} / \mathrm{P}_{1}$ is the ratio of secretory rates for the second (test) culture period to secretory rates during the first (baseline) secretory period.During the test culture period some sets of explants were incubated without addition of methacholine to the culture medium (controls). Means and standard errors of the means for each secretory product are graphed. Significance of differences between means from control and stimulated explants was assessed by the paired t-test.

tose ratios of secreted glycoproteins as a function of increasing age was not significant. In contrast, the amount of fucose present in mucous glycoprotein increased significantly between the newborn period and childhood.

Histechemical observations of mucous glycoproteins in the preterm and newborn tissues used for culture experiments are recorded in Table 3. Amounts of stored mucous glycoprotein did not vary appreciably with age. Mucus-containing cells characteristically gave an alcidic blue or purple staining reaction with the $\mathrm{AB}(\mathrm{pH} 2.5)-\mathrm{PAS}$ sequence at all ages. I.ess than 10\% of the gland cells in tracheas of preterm and full term newborns gave the pink staining reaction of neutral glycoproteins with this stain. less than $50 \%$ of cells in all tracheal tissues stained blue or purple with $A B$ (pH 1.0)-PAS. indicating the presence of sulfated glycoprotein. However, full term tracheal glands generally had less than $25 \%$, whereas preterm tracheas generally had more than 25\%; of cells which displayed the sulfate staining reaction. This distribution of cells containing sulfated glycoprotein was confirmed by HID-AB and $A B-A F$ staining sequences.

Loss of $A B$ staining at pH 2.5 with prior sialidase treatment was more extensive in full term tracheal glands. However. all but one preterm trachea had at least a small number of gland cells with sialidase-susceptible contents.

Goblet cells of the surface epithelium were sparse in most preterm tracheas, but when present they had acidic statining properties with $\mathrm{AB}$ ( $\mathrm{pH} 2.5)$-PAS and were predominantly sulfated an demonstrated by $A B(\mathrm{pH} 1$ 1.(1)-PAS. HID)-AB, or ABAF stains. Goblet cells were more abundant in full term tracheas hut displayed the same histochemical properties as these in preterm tracheas.

\section{DIST (ISSion}

Our findings suggest that tracheobronchial secretions of infants horn before 32 weeks' gestation are relatively deficient in lysozyme for a number of datys after birth and that the rate of

Table 2. Compositional changes of mucous glycoprotein secreted by tracheal explants as function of age'

Tratchea source

Premature newhorns Term newborns

(hildren (2-8 years)
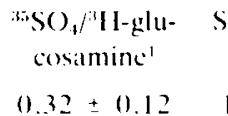

1 Iabeling expressed as disintegrations per min incorporated into secreted macromolecules per $10^{\text {t5 }} \mathrm{dpm}$ of each isotope added to culture medium.

Table 3. Histoche'mical staining properties of trache'al gland cells.

\section{Source and staining reaction' \\ Preterm newhorns \\ For sulfate $(A B$ (pH 1.())-PAS) \\ For sialidase-sus- ceptible con- tents}

Full term newhorns For sulfate (AB (pH 1.0)-PAS

For sialidatse-susceptible contents
No. of tracheals with indicated "f cells giving staining reatction

$$
0-25 \% \quad 25-50 \% \% \quad 50-75 \% \quad 75-100 \%
$$$$
3
$$$$
4
$$$$
\text { () }
$$$$
6
$$$$
1
$$$$
\text { () }
$$

' AB: Alcian bluc: PAS: periodic acid-Schiff. 
lysozyme secretion is not increased by cholinergic mechanisms in these preterm infants. Studies of serum $(18)$ and amniotic fluid (10) lysozyme as a function of gestational age also show 2-3-fold increases of activity during the third trimester. It appears that mechanisms for synthesis and discharge of lysozyme by several human tissues, including leukocytes which generate serum lysozame, are not fully functional until relatively late in gestation.

A deficiency of lysozyme in tracheobronchial secretions maly reduce the antibacterial capacity of the tracheobronchial tratet in very small preterm infants. Lysozsme has a bacteriolytic effect on gram-positive bacterial and along with complement and immunoglobulins may play a role in the destruction of gramnegative bacteria (13).

In contrast to an immaturity of the lysogme-secreting system. the mechanism for secretion of mucous glecoprotein is well developed by the end of the second trimester of pregnancs. Baseline quantities released in sitro, and in response to cholinergic stimulation by preterm explants. are equivalent to those of term newborns and older children. For the first time clearly separable mucous glecoprotein and lisognesesereting swstems in human tracheobronchial tissue have been demonstrated. Previous work demonstrated parallel secretory rates for these two protein components from unstimulated and stimulated tracheal explants of older children and adults (3). suggesting a common cell of origin. The present results. coupled with the observation that serous cells of tracheobronchial glands appear only near term (7). suggest that serous cells ecerete lysozme whereas mucus eds are the primaty source of mucous glycoproteins.

Minor atge-related changes in composition of mucous glveoproteins secreted by explants are demenstrated in these studies. The content of galitetose. glucosamine, and galactosamine, the three sugar moicties which form the oligesaccharide cores of human and mans other mucous glecoproteins (17). is comstant from 26-32 week of gestational age to childheod. I ess sulfation and greater sialic acid and fucose incorporation seem to excur with increasing age but only a change in fucose content is strongly supported he the present studies. The validity of a small sulfate-sialic acid shift is supported both by histochemical observations and chemical studies of secretions from the same tissues.

Our chemical and histochentical obervations differe from the histochemical observations of I amb and Reid (9) who described sulfated mucous glscoproteins. devoid of sialic acid. in mearly all gland cells of fetal (15-26 wechs gestation) tracheas and the appearance of sialidase-susceptible secretory matterial onls after several months of extrauterine life. Mucous glecoprofein in tratcheal tissue from the soungest subjects in our stude did not stain uniformly for sulfate; virtually all preterm tracheal glands and their secreted glycoproteins contained some sialic acid. Differences between our observations and those of I amb and Reid are not readily explained. hut mas relate in part lo gestational atge differences and/or to changes which mal hate occurred during extratuterine life, which was experienced by all of our trachea donors. The close correlation between results of chemical analyses of newborn tracheal secretions and histochemical analseses of stored secretions strengthens our clatim that onl modest changes of glecoprotein compesition oceur after 20 wechs of gestation Further support for this ditim comes from the histochemical studies of Lev (11), which demonstrated staining reactions for both sialic acid and sulfate in humatn fetal tracheobronchial glands.

An apparently higher secretory rate for mucous glecoproteins from tracheal explants of newberms. expecialls preterm. can be attributed to an increased gland densits at carls gestational ager (6). Nucous glycoprotein secretors rate per gland mass in ritro probably varies litte with age. Since ciliats movement is initiated eats in the second trimester of pregnancy (7). the two major components of a functioning mucociliars apparatus are present by 26 weeks of gestation. In fact. We have observed carbon particle tramspont at a rate approaching $1 \mathrm{~cm} / \mathrm{min}$ on the surface of explanted tracheal epithelium from newborns of $20-$
32 weets gestation. The effect, if any of shifts in sulfate sialic acid. and fucose content of the mucous glycoproteins on mucociliars transport of particles shoukd be the subject of future investigations.

\section{CONCITISION}

Bascline rates for secretion of mucous glycoprotein and secretion of this glveoprotein in response to methacholine are similar. whether from trachea explants of preterm newhorms, full term newborms, or older children. A trend toward less sulfation of glycoprotein and toward more sialic acid and fucose incorporattion wats noted with increasing age. In contrast, tracheal explants from preterm newborm had a low secretors rate for lysozme and were refractors to cholinergic stimulation. These results suggest that lysozyme secretion is deficient in the tracheobronchial airways of preterm newborm. but that the mucous-secreting system in these airwass is functioning adequately by the carliest age of viability.

\section{RIHIRINCIS ANI) NOTIS}

1. Boat. T. F., and cheng. P. W.: Mucous glycoproteins. In: J. Mangos and R. Ialamo: (ystic Fibrosis: Projections into the Future, p. 165 (Stratton Interontinental Medical Book (orp.. New York. 1976)

2. Buatt. T. F.. Cheng. P. W.. Iyer, R. N.. Carloon. D. M.. and Poluny. 1 lluman respiratory tratet sccretions: Mucous glycoproteins of nonpurulent tracheobronchial secretions and sputum of patients with bronchitis and cystic fibresis. Arch. Biochem. Biophys.. 177: 95 (1976).

3. Buat. T. F.. and keleinerman. J. I.: Human respiratory tritet secretions. 2. Effect of cholinergic and adrenergic agents on in vitro releatse of protein and mucous glycoprotecin. ( hest. 67: $325(1975)$.

4. Boat. T. F.. Kleinerman. J. I.. (arkon, D) M.. Maloney. W. H.. and Matthews. 1. W .: Human respiratory tract secretions. I. Mucous glveoprot teins secreted by cultured nasid polyp epithelium from subjects with allergeic rhinitis and with cystic fibrosis. Amer. Rev. Revp. Dis., /10: $+28(1974)$

5. Boatt. T. F. Kkeinerman, J. I. Fanaroff, A. A.. and Matthews. 1. W. Texie cffects of oxyeen on cultured human neonatal respiratory epithelium. Pesdiat. Res., 7: 607 (197.3)

6. Bucher. (1.. and Reid, I ..: Development of the mucus-secreting elements in human lung. Thorax. 16: $219(1961)$

7. de Haller, R.: Development of mucus-secreting elements In: J Imery: Antomy of the Develeping L ung, p. y4 (William Heinemann Medicil Books L.td.. Lalvenham, England, 1969).

8. L.amb. D.. and Reid 1..: Histochemical types of acidic glycoprotein produced mucenus cells of the tratheobrenchial glands in man. J. Path.. 98: 21.3 (1)(6)

9. 1.amb, 1)., and Reid 1..: Acidic glveopreteims produced by the mucous cells at the bronchial submucosal glatnde in the fetus and child: $A$ histochemical autoradiographic study. Brit. J. Dis. (hest. 66: $248(1972)$

10. 1 aren. B.. (ialank, R. P.. and Snvder, 1. S.: Muramidase and peroxidane actisity of human amniotic flude ()bstet. (ivnecol. 4.4: 219)(1974).

11. Ier. R.: A histochemical study of glyeogen and mucin in developing human fictal eprotheliat. Histuchem. J.. l: $152(1908)$

12. I ex. R ., and Spiecr. S. S.: Specific staining of sulphate group with alcian blue at low pH. J. Histuchem. (ytuchem.. 12:30)(1964).

13. Masson, P. L... and Heremans, J. F.: Sputum proteins In M. Dulfino: Sputum, p. 436 (Charles ( Thomas. Springfield. III.. 197.3).

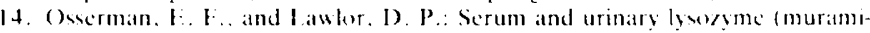
dase) in monecytic and monomyelesytic leukemia. J. Fxp. Med.. 124: 1/21 (1967).

15. Spicer. S. S.: Diamine methode for differentiating mucosubstances histench icitly. J. Histochem. (ytochem.. 1.3: $211(146.5)$.

16. Spicer. S. S.. and Meyer, D). B.: Histochemical differentiation of accid mucespolvaccharides by means of combined aldehode fuchsin-alcian blue waining. Amer. J. ( lin. Path.. 3.3: $453(1960)$

17. Spiro, R. (i.: Cilycoproteins. Adwan. Protein (hem.. 27: 349 (1973)

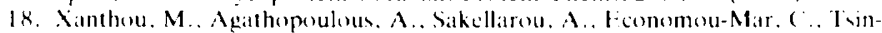

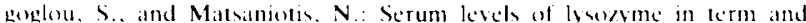
preterm newborms. Arch. Dis. (hildhend, 50: 304 (1975)

19. Postmortem tratcheal tissue was obtained with permiston of parents as approved by the Human Experimentation ( ommittee of I Inicersity Hexpitith. Cleveland.

20. We wish to thank llona Polons. (arole latfaldano, and Fleanor (Otdham tor skilled lechnical assistance. and members of the Department of Patholugy at University Itospitals for assistance in the prompt procurement of pesemortem tritcheal tisuce

21. This reseitrch was supported in part by grants 111.14884 and 11852957 from the Inited States Public Health Service and a grant from the Health fund of ('leveland

22. Recuests for reprints should he addresed to: T, F. Bentt, M. D. Rainhow Babies and (hildrens Hospital, 210.3 Adellert Roid. Cleveland. (Ohio $4+100(1 S \mathrm{~S} A)$

23. Received for publicition November 1. 1976

24. Accepted for publication february $15,1977$. 